\title{
Archaeology and the State
}

\author{
Sean Brown
}

\begin{abstract}
Archaeology is a powerful tool for the provision of a cultural identity to a population. This same power often makes it also the target of manipulation by a state in the process of nation-building. This paper will study the darker political nature of archaeology by examining the effects of state-control over archaeological resources and research, in Nazi Germany and Fascist Italy. The aim of this paper is to highlight the dangers posed to the public worldview of a nation in which the only accepted interpretation of the classical past is that of the Party.
\end{abstract}

\section{Introduction}

Archaeology provides a window to the past which is able to help clear away the mists of time; it gives insight into those periods for which there is no written evidence. However, the very nature of archaeology makes it inherently dangerous. Because archaeological data is in itself ambiguous, it is left up to the archaeologist to analyse the data and provide the most plausible interpretation based on what is found. This very ambiguity is where the danger arises; it provides a means for a state to manipulate data for ulterior, often nationalistic, purposes.

Archaeology may be used as a powerful tool in the building of nations; it can provide a sense of identity for the subjects of a sovereign power, be that power monarch, dictator, or assembly; it can provide justification for militant, expansionist policies within those powers to reclaim land that was once, supposedly, inhabited by their ancestors; it can confirm or invalidate the historiography of ancient peoples; it can create the pretext for genocide, and a false sense of racial superiority. For all of these reasons, it is imperative that archaeological data be analysed with the most severe sense of objectivity else it be manipulated, or wholly fabricated, as was done in Germany during the first half of the twentieth century.

This paper will look at some of the ways that archaeology is used by nation-states as a means of consolidating power, and fostering a sense of national identity around which the population may rally together. In so doing, it will be elucidated how nationalism is prone to manipulate the past, via misrepresentation of the archaeological record, for the further advancement of a nation-state. The effects of such manipulation of the past will be made clear with an analysis of the abuses, misrepresentation, and fabrications of the archaeological record by the Third Reich in Nazi Germany, and through the creation of a mythologised past to aid in the creation of a "New Rome" by Benito "Il Duce" Mussolini in Fascist Italy. These two nations provide stunning examples of the dangers presented by archaeology, and the ancient world itself, when analysed with a biased eye, and intentionally misrepresented in the interests of a totalitarian state.

\section{Archaeology in the Service of the State}

In the service of the state, archaeology can bring a great deal of credibility to the messages being broadcast to a population, giving a sense of scientific absolutism to what is heard. Part 
of the success of such practice, and where the danger of misrepresentation is most pronounced, is that the lay person hearing of the results of archaeological analysis does not have the knowledge or means to confirm such things as they hear; they must rely on truthful representation of the facts. A primary cause of misrepresentation is to be found in the source of funding that is used for the conducting of archaeological research and excavation. Funding for research and excavation often, if not always, comes from the state. As such, it is the state that controls what is important, and what will be disseminated publicly.

The primary function of nationalist archaeology is to foster national unity through a feeling of mutual pride, regardless of class boundaries that may otherwise socially separate a population. ${ }^{1}$ This function piques the interest of the state in archaeology through the availability of tools made available for the creation of a unified national identity, especially where ethnicity is concerned. National and ethnic identities are inherently linked to one another through being both constructions of a social climate, and having the ready potential to be manipulated for social, political, and economic reasons. The power of archaeology in creating such identities is to be found in the use of data to provide for a notion of static inhabitation in a region stretching back into the remotest of antiquity and beyond; tying together a population based on shared geographic and cultural origins. ${ }^{2}$ It is the funding provided by the state in the interest of creating this national identity that leads to the building of museums, and the subsequent populating of those museums with artefacts and other such things as may be made immediately accessible to the public as a means of identifying with their perceived shared cultural history.

Unfortunately, that very interest in archaeology that leads to the provision of state funding required by the discipline is also a source of bias for some archaeologists. The temptation to selectively interpret and present data in such a fashion as to ensure it will be desirable by the state, and therefore provide a means of publicity and career advancement for the archaeologist, is all too real. Archaeologists have an ethical responsibility to be aware that their views may be commandeered for political purposes and to ensure that any interpretation of data is free from bias, regardless of whether or not the conclusion is one which those providing funding for research want to hear. Indeed, inter-archaeologist analysis of identical data-sets, regardless of politics, should reach the same conclusion provided that there is no bias in the interpretation of any given researcher. Certain ethical standards related to the use of archaeological data in the creation of a nationalist identity must be acknowledged. It is imperative that archaeological data being used in the service of the state do not create a national past for one group at the expense of another; that the cultural traditions of all groups be recognised as being worthy of study and respect; that the construction of a national past through the use of archaeological data does not entail the abandonment of a universal perspective of common humanity, nor the abandonment of the past and future being shared between all. ${ }^{3}$

\section{Archaeology in Nazi Germany}

Perhaps one of the most striking examples of the danger posed by the manipulation of archaeology by a state is that of Nazi Germany. In Germany during the early twentieth

\footnotetext{
${ }^{1}$ Bruce G. Trigger, “Alternative Archaeologies: Nationalist, Colonialist, Imperialist,” Man 19 no.3 (1984): 360.

2 Philip L. Kohl, "Nationalism and Archaeology: On the Constructions of Nations and the Reconstructions of the Remote Past," Annual Review of Anthropology 27 (1998): 231, 239.

3 Ibid., 243.
} 
century, there was a severe lack of national self-esteem following the results of The Great War and the subsequent sanctions placed on Germany as a result. These conditions resulted in a perfect climate for nationalist archaeology to flourish as a means of rebuilding German pride. German archaeologists such as Alexander Ecker and Gustav Kossinna were on the forefront of creating and supporting racial and expansionist ideologies of supremacy which were readily accepted by both the leaders, and general population of Germany; though their theories on race and prehistoric population distribution would never be accepted by the entirety of the intelligentsia, many of whom would lose their careers in light of their opposition to party doctrine.

Kossinna developed a model of cultural diffusion which entailed a passing of knowledge and ideas from more-advanced peoples to those which were less-advanced. From this premise, Kossinna further developed his theory into a model of settlement-archaeology which would later be used to provide justification for expansionism by the Nazi state, especially into Slavic territories. Kossinna used a comparison of Slavic and Germanic pottery as an example of the superiority of the German people over their eastern neighbours when he noted that Slavic pottery was of "shocking crudeness" when held against Germanic samples; the power of rhetoric in fostering national pride makes itself readily apparent in examples such as this. From his observations, Kossinna concluded that the pottery wheel had only reached the Slavic peoples through diffusion from Germanic populations. The settlement-archaeology model developed by Kossinna stipulated that the material remains obtained through archaeological excavation could be used to provide concrete boundaries between various populations through many ages. ${ }^{4}$

The suitability of such biased prehistories for use as political propaganda becomes readily apparent in the very uniforms of party members in Nazi Germany. Potent symbols of Germanic antiquity such as the swastika became symbolic of the Third Reich, while a certain runic symbol, reminiscent of a lightning bolt, adorned the shoulders of members of the SS. ${ }^{5,6,7}$ The National Socialists readily pushed the new Germanic prehistory as a potent method of fostering national and racial pride. The history taught to the Hitler Youth stressed a glorious, imperial past for Germany; this history, and the maps which illustrated and supported it, was directly based on the work of Kossinna and his students in the school of settlement-archaeology. ${ }^{8}$

Ecker conducted anthropomorphic analyses of skeletons exhumed from the South German Reibengräbertypus cemetery. In his findings, Ecker noted a specific Germanic-type of human with great body length and long skulls. This observation, however distorted and stereotyping, furthered the belief that the German people were unique among humanity. Regardless of the credibility, or lack-there-of, of the findings of Ecker, his observations would be used to fabricate evidence to sustain the myth of the Germanic-type. The Ecker physiological model was employed in the interest of nationalism, by the intentional

\footnotetext{
${ }^{4}$ Bettina Arnold, “The Past as Propaganda: Totalitarian Archaeology in Nazi Germany, ” Antiquity 64 (1990): 464; Ingo Wiwjorra, "German Archaeology and its Relation to Nationalism and Racism," in Nationalism and Archaeology in Europe, ed. Diaz-Andreau et al. (London: UCL Press, 1996), 174.

5 Arnold, "The Past as Propaganda," 469.

${ }^{6}$ Bernard Mees, "Hitler and Germanentum," Journal of Contemporary History 39 no.2 (2004): 255.

7 Ingo Wiwjorra, "German Archaeology and its Relation to Nationalism and Racism," in Nationalism and Archaeology in Europe, ed. Diaz-Andreau et al. (London: UCL Press, 1996), 178.

8 Bernard Mees, "Hitler and Germanentum," Journal of Contemporary History 39 no.2 (2004): 260.
} 
falsification of cranio-metric measurements of German recruits, in order to dishonestly confirm the anthropomorphic uniqueness of the German people.'

By using the settlement-archaeology model of Kossinna, archaeological remains from all over northern and western Europe were used to demonstrate the cultural pervasiveness of the Germans, however tentative the actual link to Nordic/German culture really was. This ideology would find great significance for Adolf Hitler in providing justification for his ideology that the Aryans were an original type of human-being, who were the founders of culture and superior to mere carriers of culture. He even went so far as to credit the accomplishments of classical antiquity to the blonde Aryans. ${ }^{10}$ These supposed links between the German people of the twentieth century and such a large swath of ancient Europe provided a significant amount of justification for the expansionist policies of Nazi Germany; they showed that lands now under non-German control were once German, and must become German once again. This ideology is exemplified perfectly by the German ethnic prehistorian Karl Felix Wolff who wrote that "the next bimillenium will be the age of the Germans, for German history is just repeating Indo-German history and the world is about to become German in the way it once became Indo-German.",11

Among the critics of the racist doctrines formulated by men such as Kossinna and Ecker was Gerhard Bersu. Bersu was prematurely retired from his directorial post at the Römisch Germanische Komission by the National Socialist party because he had refused to condone the Kossina-school of racist, nationalist doctrine or conduct any research which was tailored to the National Socialist agenda. ${ }^{12}$ If the voices of opposition were not blatantly silenced, they were simply ignored. In addition to Bersu were other members of the German intelligentsia who attempted, in vain, to maintain standards of objectivity within the field of archaeology. However, regardless of their appeals to reason, without support from the Party, organised resistance was impossible. ${ }^{13}$

Foremost among the causes for the pre-eminence of German prehistory during the Third Reich was the funding which was brought to the discipline by the Party. Within two years of Hitler ascending to power, eight new chairs of prehistory were created. With the creation of these new chairs came an unprecedented level of funding for excavation which opened the doors of all of Eastern Europe to the trowels of German archaeologists. Their finds would fill the halls of newly opened museums such as the Nachrichtenblatt für Deutsche Vorzeit, which began operation in 1939. ${ }^{14}$ Archaeological sites themselves were turned into open-air museums in a, very successful, effort to popularise German prehistory. One such open-air museum was that of a Neolithic-Bronze Age settlement at Unterubldingen on Lake Constanz. ${ }^{15}$

In light of the censuring of Bersu and his colleagues, it is important to understand the temptations faced by some archaeologists to go along with the ideology of the National Socialists out of the interest of professional self-preservation. The ideological goals of the National Socialists led to preconceived notions of what would be found in the archaeological past, aided in no small part by the settlement-archaeology school of thought established by

9 Wiwjorra, “German Archaeology," 170.

10 Ibid., 177, 179.

11 Ibid., 171.

12 Arnold, "The Past as Propaganda," 472.

13 Ibid., 473.

14 Ibid., 468.

15 Ibid. 
Gustav Kossinna. ${ }^{16}$ The archaeological spirit of the Third Reich is no better elucidated than through the words of one of their own top archaeologists, Hans Reinerth:

German archaeology is for me...indigenous, blood-bound Germanic and Indo-Germanic prehistory. In no way should it be concerned with the history of the Roman or Slavic alien cultures on German soil...Our spadework has the pre-eminent goal... of illuminating our hitherto neglected indigenous prehistory. Anyone who opposes this effort is a pernicious threat to the German people and should be fought accordingly. ${ }^{17}$

These racist and nationalist goals, combined with the stiff professional penalties for dissenters, effectively removed the ability and will of researchers to conduct analysis that did not agree with Party doctrine. This example should serve to illustrate how important it is for the archaeologist to understand how easily standards of ethics for the national use of archaeology may be subsumed in the interests of the state.

\section{The Myth of Romanità}

The use of the past by the Italian Fascist Party during the early twentieth century was fundamentally different from the situation that occurred in contemporary Germany. In Italy, it was classical archaeology, rather than the prehistoric archaeology so favoured by their German counterparts, that would reach the level of academic supremacy. ${ }^{18}$ There was no need to create a false archaeology of the Roman world, sites and monuments abounded which would provide Mussolini with the propaganda tools that he needed to create the "New Rome" of his vision. Instead of creating a new past based on racial and cultural supremacy the way men such as Kossinna had done for Germany, the Italian dictator stressed a continuity between the acknowledged past of Roman antiquity and the newly united country of Italy. In so-doing, he was attempting to bring into existence a new way of life for the Italian people. This new way of life was called Romanità, in essence "Romanness", and was the corner-stone of the ideal of Mussolini to bring a new Roman Empire to the world stage.

The myth of Romanità concocted by Mussolini was, as previously mentioned, an active attempt to link modern Italy with ancient Rome, specifically to the early imperial period. The fasces, tools of the ancient Roman lictors and symbols of imperial authority, were quickly brought back to the foreground. These bundles of rods and axes soon became required decòr for all public works, and were immediately pressed into coin through the designs of Italian archaeologist Giacomo Boni. ${ }^{19}$ The increasingly public nature, and intensity, of the attempts of the Fascist Party to link itself, and thereby the people under fascist rule, to the world of ancient Rome through all manner of media speak to the pervasiveness of the myth of Romanità in contemporary Italy. Printed propaganda; archaeological excavations such as that conducted on the Ara Pacis Augustae ${ }^{20}$; public ceremonies such as that in which, following the conquest of Ethiopia, Mussolini personally delivered a fasces to the Capitoline

\footnotetext{
16 Bettina Arnold, “Arierdämmerung: Race and Archaeology in Nazi Germany," World Archaeology 38 no.1 (2006): 11-12.

${ }^{17}$ Ibid., 12.

18 Alessandro Guidi, "Nationalism Without a Nation: The Italian Case," i n Nationalism and Archaeology in Europe, ed. Diaz-Andreau et al. (London: UCL Press, 1996), 110.

19 Peter Aicher, "Mussolini's Forum and the Myth of Augustan Rome," The Classical Bulletin 6 no.2 (2000): 119.

20 Ibid, 124.
} 
to be dedicated in mimicry of a passage from the Res Gestae of Augustus ${ }^{21}$; stamps featuring images of Augustus ${ }^{22}$; symbols such as the fasces themselves; cinema, and scholastic instruction $^{23}$ all served to underline the significance of Romanità. Romanità was more than simply an ideology; under the leadership of Mussolini, Romanità was to become a way of life in which Italy was to actually become Roman once again through the example of their forebears.

Architecture erected under the guide of fascism was also reflective of the grand, imperial notions harboured by Mussolini. Italian architect Mario Sironi designed a room for the Mostra della rivolurione fascista, an exhibition of the fascist revolution which was held in 1932, that placed emphasis on the monumental nature which the fascists wished to portray for their new nation. In the monumental "Salon of Honour" designed by Sironi, "the roughhewn Roman sword, the chiselled DUX, the hall of fasci all hearkened back to a mythic age. The grand scale and archaeological ${ }^{24}$ feel gave Sironi's rooms a sense of timeless authority authority connected to a mythologised Italian past." 25 In an effort to dominate the modern city of Rome, while recalling the glorious past which was so stressed by the fascists, Mussolini had built his own Colosseum: il colosseo quadrato, which continued to dominate the area in which it resided until well after the fall of fascism. ${ }^{26}$ The Via dell'Impero, also built by the fascists, cuts directly through the historic centre of Rome connecting the Colosseum (ie Flavian Amphitheatre) with Piazza Venezia, from where Mussolini would deliver his speeches to the populace.

With the return to ancient Rome now firmly entrenched into the heart of the fascist movement, classical archaeology in Italy would enjoy a form of perverse renaissance during the early twentieth century. Mussolini recognised that classical archaeology would be an important weapon in his propaganda war against those of sane mind, and from very early on "Il Duce" was an important player in the realm of archaeology on the Italian peninsula. ${ }^{27}$ In his dictatorial position within Italian classical archaeology, Mussolini focused on a so-called restoration of Rome. The svegliamenti program of systematic destruction of archaeological sites in the interest of restoring Rome is somewhat problematic due to the logical disconnect between the two notions, but it can be made more clear if recognition is given to the fact that Mussolini did not want to "restore" ancient Rome per-se. Rather, he wanted to restore those parts of ancient Rome which contributed to glory, and imperialist justification; Mussolini was not in the game of historical restoration. The Via dell'Impero covers the imperial fora in a stellar example of how the fascist interest of "restoring" Rome had very little to do with actual restoration, or protection of archaeological sites for that matter.

Like their German contemporaries, the National Socialists, the Italian fascists relied on a strict level of censorship to ensure that their programs were seen to have as little opposition as possible. The intelligentsia of Italy during the fascist period were required to swear an

\footnotetext{
${ }^{21}$ Ibid, 137.

22 Ibid, 123.

23 Ibid, 119.

${ }^{24}$ Emphasis inserted by the author.

25 Maria Stone, "Staging Fascism: The Exhibition of the Fascist Revolution," Journal of Contemporary History 28 no.2 (1993): 225.

26 Jan Nelis, "Constructing Fascist Identity: Benito Mussolini and the Myth of Romanità," The Classical World 100 no.4 (2007): 408.

27 Ibid, 411-412.
} 
oath of allegiance to Mussolini ${ }^{28}$ effectively making speaking out in dissent against the regime amount to an act of treason. However, the tacit acquiescence by the intelligentsia of fascist ideology was from a more significant source than simply fear. In addition to the overt threat of punishment for dissidence inherent in swearing allegiance to Mussolini, the ideology of Italian fascism and Romanità created a divide between the scientific objectivity of archaeology-proper, and the aggrandisement of the past through the use of propaganda. This ideological divide brought with it the "preconditions for the frightening decline in the work and research methods of historians and archaeologists during the fascist period." ${ }^{29}$ With opposition from the intelligentsia of Italy silenced, fascist control of the minds and ideologies of the populace was inevitable.

\section{Conclusions}

Throughout the context of this paper, it has been attempted to bring to light the many dangers faced by archaeologists in their interpretations of the prehistoric and ancient worlds. Being the powerful tool for social organisation and nation-building that it is, archaeology is inherently predisposed to manipulation in the interest of the state, especially if that state happens to have totalitarian control over the scholars which reside in it. Though many archaeologists would never intentionally falsify data, it is important to learn from the lessons of archaeological and historical abuse by the National Socialists and the Italian fascists that approaching research with preconceived notions can very easily result in the dismissal of contradictory evidence as being anomalous or, worse yet, worthless.

There will likely never be any way of truly bringing to light all of human antiquity. With this in mind, it is of the utmost importance that archaeologists remain objective and thorough in their excavations, and avoid the wonton destruction of the past in the interest of the future as was done, with the utmost vigour, in Italy during the early twentieth century. It is impossible to think that every archaeological site may be saved, but through diligence of recording practices it is possible that those sites which are destined to fall before "progress" may live on in scholarship and not be lost to the sands of time. Recognition by archaeologists, and the public, of the political nature of the discipline may help to prevent such abuses of the past from occurring again. New forms of access to information, such as the internet, give the public the ability to verify, however tentatively, the information which they will be inevitably exposed to. An interest in the past and our origins is something which has been a part of humanity throughout history, being the very reason that the field of history exists. By appreciating the abuses of history, and archaeology by certain powers in the past, those same abuses may be prevented in the future. As always, those who disregard history are doomed to repeat it.

\footnotetext{
28 Peter Aicher, "Mussolini's Forum and the Myth of Augustan Rome," The Classical Bulletin 6 no.2 (2000): 139.

${ }_{29}$ Alessandro Guidi, "Nationalism Without a Nation: The Italian Case," i n Nationalism and Archaeology in Europe, ed. Diaz-Andreau et al. (London: UCL Press, 1996), 113.
} 


\section{Bibliography}

Aicher, Peter. "Mussolini’s Forum and the Myth of Augustan Rome." The Classical Bulletin 76 no. 2 (2000): 117-139.

Arnold, Bettina. "The Past as Propaganda: Totalitarian Archaeology in Nazi Germany.” Antiquity 64 (1990): 464-478.

Arnold, Bettina. “Arierdämmerung: Race and Archaeology in Nazi Germany.” World Archaeology 38 no.1 (2006): 8-31.

Guidi, Alessandro. "Nationalism without a Nation: The Italian Case." In Nationalism and Archaeology in Europe, edited by Díaz-Andreu, Margarita García. and T. C. Champion, 108-118. London: UCL Press, 1996.

Kohl, Philip L. "Nationalism and Archaeology: On the Constructions of Nations and the Reconstructions of the Remote Past." Annual Review of Anthropology 27 (1998): 223-246.

Mees, Bernard. "Hitler and Germanentum." Journal of Contemporary History 39 no.2 (2004): 255-270.

Nelis, Jan. "Constructing Fascist Identity: Benito Mussolini and the Myth of Romanita." The Classical World 100 no.4 (2007): 391-415.

Stone, Maria. "Staging Fascism: The Exhibition of the Fascist Revolution." Journal of Contemporary History 28 no.2 (1993): 215-243.

Trigger, Bruce G. “Alternative Archaeologies: Nationalist, Colonialist, Imperialist.” Man, New Series, 19 no.3 (1984): 355-370.

Wiwjorra, Ingo. "German Archaeology and Its Relation to Nationalism and Racism." In Nationalism and Archaeology in Europe, edited by Díaz-Andreu, Margarita García, and T. C. Champion, 164-187. London: UCL Press, 1996). 